Deeming, D. C., L. E. Biddle, and C. R. Du Feu. 2017. Interspecific and intraspecific spatial separation by birds breeding in nest boxes. Avian Conservation and Ecology 12(2):1. https://doi.org/10.5751/ACE-01026-120201

Copyright (C) 2017 by the author(s). Published here under license by the Resilience Alliance.

Research Paper

\title{
Interspecific and intraspecific spatial separation by birds breeding in nest boxes
}

\author{
Denis C. Deeming ${ }^{1}$, Lucia E. Biddle ${ }^{1}$ and Christopher R. du Feu ${ }^{2}$ \\ ${ }^{1}$ University of Lincoln, ${ }^{2}$ Treswell Wood Ringers Group
}

\begin{abstract}
Nest boxes can be seen as a conservation tool for improving low-grade nesting habitat but it is unclear how sympatric species using boxes establish a spatial distribution relative to conspecifics and heterospecifics. This study determined the distances between nest boxes occupied by Blue Tits (Cyanistes caeruleus) and Great Tits (Parus major) in two British woodlands to ascertain whether spatial distribution was affected by species and, if it was, whether there were reproductive consequences of this breeding distribution. Occupancy of nest boxes at two woodland sites were recorded on an annual basis between 2010 and 2014 , inclusive. Distances between nest boxes, and reproductive activity, were recorded. Even if nest boxes showed a clumped distribution in the woodlands, the occupancy of the boxes was random. Not all boxes were used and the minimum distance between occupied boxes was at least twice the distance between boxes in general. Blue Tits tended to have greater distances between boxes containing conspecifics but distances between boxes containing heterospecifics were generally of comparable lengths. Reproductive output was only affected in relation to clutch size for Blue Tits nesting at one site. Nest boxes that aim to improve habitats that lack suitable nesting sites should be placed to reflect actual dispersal distances of the focal bird species.
\end{abstract}

\section{Séparation spatiale interspécifique et intraspécifique d'oiseaux nichant dans des nichoirs}

RÉSUMÉ. Les nichoirs peuvent être considérés comme des outils de conservation pour améliorer les milieux de nidification de mauvaise qualité, mais on ne sait pas comment les espèces sympatriques utilisant les nichoirs établissent une répartition spatiale relativement aux individus conspécifiques et hétérospécifiques. La présente étude avait pour but de déterminer les distances entre les nichoirs occupés par les Mésanges bleues (Cyanistes caeruleus) et les Mésanges charbonnières (Parus major) dans deux boisés britanniques afin de vérifier si la répartition spatiale était influencée par les espèces et, le cas échéant, s'il y avait des conséquences sur le plan reproductif de cette répartition de nidification. L'occupation des nichoirs à deux sites boisés a été colligée annuellement de 2010 à 2014 inclusivement. La distance entre les nichoirs et l'activité reproductrice ont été notées. Même si les nichoirs montraient une répartition groupée dans les boisés, leur occupation était aléatoire. Tous les nichoirs n'étaient pas occupés et la distance minimale entre deux nichoirs occupés était au moins le double de celle entre les nichoirs en général. Chez la Mésange bleue, les distances entre les nichoirs occupés par des individus conspécifiques étaient plus grandes, mais les distances entre les nichoirs occupés par des individus hétérospécifiques étaient généralement de longueurs comparables. La seule composante affectée du succès reproducteur était la taille de ponte de la Mésange bleue nichant à un site. Les nichoirs dont l'objectif est d'améliorer l'habitat là où il manque de sites de nidification propices devraient être installés pour refléter les distances de dispersion réelles des espèces d'oiseaux ciblées.

Key Words: Blue Tit; Great Tit; nearest neighbor distances; nest box; reproductive success

\section{INTRODUCTION}

Provision of nest boxes is a conservation measure by which habitats can be made attractive to species for breeding (Mänd et al. 2005, Sánchez et al. 2007, Lima and Garcia 2016). For instance, forestry management often removes dead or decaying trees, which can develop natural cavities, or provide sites for cavity excavation by species such as woodpeckers (Picidae; Remm et al. 2006, Sánchez et al. 2007). The absence of large diameter trees can also limit availability of natural cavities (Camprodon et al. 2008). These serve as nest sites for secondary cavity-nesting species, i.e. species that utilize existing holes rather than excavating their own, although holes created by woodpeckers or other primary cavity excavators can be durable but eventually the wood can decay and the cavity is lost (Cockle et al. 2011). Hence, for natural and human-induced reasons there can be a shortage of suitable nest sites in many woodland locations (Newton 1994, Camprodon et al. 2008, Mazgajski 2009, Cockle et al. 2011). Artificial provision of nest boxes may allow species to breed in habitats that may be suitable for various ecological reasons, such as suitable foraging opportunities, but lack appropriate natural nest sites (Newton 1994, Sánchez et al. 2007). Provision of nest boxes can allow an increase in breeding density in some, but not all, habitats (Mänd et al. 2005, Camprodon et al. 2008). However, provision of nest boxes can also lead to an ecological trap because birds may be "tied" to breeding in a suboptimal habitat (Mänd et al. 2005, Klein et al. 2007, Rodríguez et al. 2011).

In Europe, foraging competition between Eurasian Blue Tits (Cyanistes caeruleus; hereafter Blue Tits) and Great Tits (Parus major) in woodland habitats can be minimized by use of different parts of the habitat (Colquhoun and Morley 1943). However, use 
of cavities for nesting can depend on the availability of suitable natural or primary excavator cavities (Newton 1994, Camprodon et al. 2008, Mazgajski 2009, Cockle et al. 2011). If such sites are few in number in any particular location then artificial boxes may offer a suitable nest cavity and allow breeding (Sánchez et al. 2007, Camprodon et al. 2008, Lima and Garcia 2016). The locations of a population of nest boxes are chosen by humans, which may not reflect the most appropriate habitat for the different species of birds (Mänd et al. 2005, Milligan and Dickinson 2016).

Given that both Blue Tits and Great Tits are sympatric the question arises of whether intraspecific or interspecific competition determines the spatial separation of breeding birds within nest boxes provided within the habitat. Nest box occupancy shows a positive correlation with breeding bird density in both Blue and Great Tits (Minot and Perrins 1986). In Great Tits distances between boxes were affected by bird density: lower density increased the distances between nest boxes containing conspecifics (Krebs 1971). However, Green (1979) argued that although intraspecific interference was significant for both Blue Tits and Great Tits, if interspecific interference occurred then it would be relatively small.

From a conservation perspective the number of nest boxes will determine how widely they are dispersed within the available habitat, especially if they are placed to achieve maximum coverage through the available area. Be it a box, or a tree hole, the birds are unable to move the location of a cavity. Whether any cavity is occupied may depend on where it lies adjacent to any breeding territory if there is a need to minimize intraspecific interference (Gosler 1993). Building and locating nest boxes is not without cost and so conservation schemes might be more cost-effective if there is efficient placement of boxes. Nest boxes are often provided in excess because rarely are all boxes occupied (e.g., Mänd et al. 2005) but it is unclear whether this reflects the carrying capacity of the habitat or the suitability of location for nest boxes. No studies have yet investigated whether the numbers and distribution of nest boxes could be better managed to maximize breeding.

This study used two populations of nest boxes, one at Riseholme Park, University of Lincoln and the other at Treswell Wood, Nottinghamshire (hereafter Treswell). We collected data for nest box occupancy each year for the breeding seasons during 2010 to 2014 , inclusive, to study nest box use rather than breeding density. We investigated whether there was a random pattern of distribution of either all nest boxes at the two sites, or only those occupied by Great Tits and Blue Tits. We measured the distances between occupied boxes to determine whether adjacent boxes were occupied by conspecifics or heterospecifics. Given that interspecific interference is considered low between Blue Tits and Great Tits (Green 1979), it was hypothesized that the spatial separation of nest boxes occupied by conspecifics would be greater than those boxes occupied by heterospecifics. Finally, we tested the hypothesis that reproductive success would be adversely affected by shorter distances between adjacent boxes containing conspecifics but would be unaffected if nearest neighbors were heterospecifics. Our intention was to use these results to consider whether it was possible to reduce nest box numbers in an area without reducing breeding activity, and so help make provision of nest boxes in conservation situations more cost-effective.

\section{METHODS}

\section{Locations}

Riseholme Park campus, University of Lincoln $\left(53^{\circ} 16^{\prime} \mathrm{N}, 0^{\circ} 31^{\prime}\right.$ $\mathrm{W})$ has eight small interconnected areas of mainly deciduous woodland (ranging from 0.6 to 5.8 ha adding to a total of $16 \mathrm{ha}$ ) and dominated by beech (Fagus sylvatica), ash (Fraxinus excelsior), and sycamore (Acer pseudoplatanus) surrounded by arable farmland (Britt and Deeming 2011, Deeming 2013). Between 70 and 80 nest boxes (mainly with base dimensions of $115 \mathrm{~mm} \times 140 \mathrm{~mm}$ and minimum height of $155 \mathrm{~mm}$, although around $10 \%$ were larger in base area) were available during 2010 to 2014 for Blue Tits and Great Tits to use (range of densities = 4.25-5.00 boxes per ha; Table 1). Boxes were typically positioned on the north sides of trees at a height of $1.5-1.8 \mathrm{~m}$ from the ground. The number of boxes varied slightly between years because of damage and loss of boxes and addition of boxes. Placement of boxes allowed provision of potential nesting sites over most of the woodland. Nest boxes were monitored on a weekly basis during each breeding season to record the presence of a nest, the species concerned, and the reproductive output from the nest (clutch size, brood size, and number of fledged nestlings). Most boxes were occupied each year by Great Tits or Blue Tits but one or two boxes a year were occupied by Winter Wren (Troglodytes troglodytes), Coal Tit (Poecile ater), European Robin (Erithacus rubecula), or Eurasian Treecreeper (Certhia familiaris; for exact numbers see Table 1).

Treswell Wood, near Retford, Nottinghamshire, UK $\left(53^{\circ} 18^{\prime} \mathrm{N}, 0^{\circ}\right.$ $\left.51^{\prime} \mathrm{W}\right)$ is a Nottinghamshire Wildlife Trust reserve of 47 ha of mixed woodland dominated by ash with hazel (Corylus avellana) and surrounded by farmland (Deeming and du Feu 2011, MacColl et al. 2014). The number of boxes varied from 173 to 204 over the time period studied (range of densities $=3.68-4.34$ boxes per hectare; Table 1); they varied in style from standard nest boxes through to custom built cavities excavated out of tree stumps (du Feu 2003). The position of the boxes was within 2-3 $\mathrm{m}$ alongside paths within the wood and so distribution of boxes across the whole wood was not uniform. Boxes were typically positioned on the sides of trees at a height of $1.5-1.8 \mathrm{~m}$ from the ground but in no specific compass orientation. Nest boxes were monitored on a weekly basis during each breeding season as part of a long-term nest recording scheme (see Deeming and du Feu 2011) and clutch size, brood size, and the number of fledged nestlings, were all recorded. Most boxes were occupied by Great Tits or Blue Tits but a few boxes a year were occupied by Winter Wren, Coal Tit, Marsh Tit (Poecile palustris) or Eurasian Nuthatch (Sitta europaea; see Table 1).

Both sites are heavily managed; at Riseholme dead wood has all been completely felled and removed, whereas at Treswell there is an extensive coppicing regimen. Greater Spotted Woodpeckers (Dendrocopos major) are present at both sites but at low densities. At Riseholme breeding records from 2007 to 2016 indicated that use of nest boxes by Great Tits ( 20 per year) did not change over time but records of Blue Tits using boxes progressively increased from 5 to 20 boxes. At Treswell breeding records extend to almost 40 years and nest box usage by Great Tits correlated with nest box provision whereas numbers of breeding Blue Tits remained quite stable (Gillingham, du Feu, and Deeming, unpublished data). At neither site were there systematic searches for natural nest sites 
Table 1. Summary of the number of nest boxes at each site, Riseholme Park (RP) or Treswell Wood (TP), and the number of boxes occupied by the species indicated for each year. Zero indicates that no cases of that species were observed that year but the species did nest during other years and a dash indicates not observed to nest in nest boxes at location.

\begin{tabular}{|c|c|c|c|c|c|c|c|c|c|c|}
\hline & \multicolumn{2}{|c|}{2010} & \multicolumn{2}{|c|}{2011} & \multicolumn{2}{|c|}{2012} & \multicolumn{2}{|c|}{2013} & \multicolumn{2}{|c|}{2014} \\
\hline & $\mathrm{RP}$ & TW & $\mathrm{RP}$ & TW & $\mathrm{RP}$ & TW & $\mathrm{RP}$ & TW & $\mathrm{RP}$ & TW \\
\hline Total nestboxes & 70 & 173 & 79 & 204 & 80 & 202 & 77 & 198 & 68 & 185 \\
\hline Total boxes occupied & 38 & 73 & 42 & 113 & 48 & 118 & 36 & 75 & 43 & 76 \\
\hline $\begin{array}{l}\text { Blue tits } \\
\text { (Cyanistes caeruleus) }\end{array}$ & 12 & 19 & 22 & 30 & 18 & 35 & 17 & 25 & 15 & 23 \\
\hline $\begin{array}{l}\text { Great tits } \\
\text { (Parus major) }\end{array}$ & 26 & 50 & 18 & 78 & 29 & 67 & 18 & 44 & 25 & 40 \\
\hline $\begin{array}{l}\text { Coal tits } \\
\text { (Poecile ater) }\end{array}$ & 0 & 0 & 1 & 1 & 1 & 1 & 0 & 3 & 2 & 1 \\
\hline $\begin{array}{l}\text { Marsh tits } \\
\text { (Poecile palustris) }\end{array}$ & - & 2 & - & 2 & - & 2 & - & 1 & - & 2 \\
\hline $\begin{array}{l}\text { Wren } \\
\text { (Troglodytes troglodytes) }\end{array}$ & 0 & 2 & 0 & 1 & 0 & 3 & 1 & 1 & 1 & 9 \\
\hline $\begin{array}{l}\text { Robin } \\
\text { (Erithacus rubecula) }\end{array}$ & 0 & - & 1 & - & 0 & - & 0 & - & 0 & - \\
\hline $\begin{array}{l}\text { Treecreeper } \\
\text { (Certhia familiaris) }\end{array}$ & 0 & - & 0 & - & 0 & - & 0 & - & 1 & - \\
\hline $\begin{array}{l}\text { Nuthatch } \\
\text { (Sitta europaea) }\end{array}$ & - & 0 & - & 1 & - & 0 & - & 1 & - & 1 \\
\hline Density of boxes per hectare & 4.38 & 3.68 & 4.94 & 4.34 & 5.00 & 4.40 & 4.81 & 4.21 & 4.25 & 3.94 \\
\hline $\begin{array}{l}\text { Blue Tit density (boxes per } \\
\text { hectare) }\end{array}$ & 0.75 & 0.40 & 1.38 & 0.64 & 1.13 & 0.74 & 1.06 & 0.53 & 0.94 & 0.49 \\
\hline $\begin{array}{l}\text { Great Tit density (boxes per } \\
\text { hectare) }\end{array}$ & 1.63 & 1.06 & 1.13 & 1.66 & 1.81 & 1.43 & 1.13 & 0.94 & 1.56 & 0.85 \\
\hline
\end{tabular}

for tit species but given the management regimens of both sites, it was assumed that natural, and excavated, cavities were in relatively low supply.

\section{Geographical distances}

For both sites the 10-digit Ordnance Survey grid reference was recorded for each nest box using a GPS unit (Garmin). The positions of the boxes were plotted and a grid of $100 \times 100 \mathrm{~m}$ squares was overlaid covering the area of woodland for each site (see Fig. 1). For each grid square the numbers of nest boxes in total, and those occupied by Great Tits and Blue Tits were recorded. An index of dispersion (Fowler et al. 1997) was calculated: variance/mean of the boxes. $s^{2} / x$ values were multiplied by the degrees of freedom (number of grid squares sampled minus one) to produce a $\chi^{2}$ value, which was checked graphically against the $95 \%$ confidence zone for random distribution to ascertain the distribution pattern.

Pythagoras' theorem was used to calculate the distance (in m) between nest boxes (Surgey et al. 2012). For each year of the study, and for each box, the following distances were calculated: (1) the distance to the nearest box; (2) the distance from a box occupied by the focal species to another box occupied by a conspecific; and (3) the distance from a box occupied by the focal species to the nearest box occupied by a heterospecific (irrespective of species). Analysis focused on data for Great Tits and Blue Tits and examined the distances between boxes containing either the same or different species. Reproductive output was measured as clutch size and the number of fledged chicks as a proportion of the clutch size. Given that the two locations were only a few kilometers apart, and on nearly the same latitude, we considered that the two geographical locations would be equivalent but we tested this in our analyses.

\section{Statistical analysis}

Data analysis was undertaken using Minitab (version 17). General linear mixed models (GLMM) were used to test the effect on distance between occupied nest boxes of focal species (Blue Tit or Great Tit) and location (Riseholme and Treswell) as fixed factors (and their interaction), while controlling for year as a random factor. Distances were $\log _{10}$-transformed prior to analysis. Effects of distance between occupied boxes on reproductive output were tested using the same GLMM model with the addition of distance as a covariate. Any correlations were studied using Spearman's signed rank tests.

In order to explore whether nests were randomly distributed with respect to the type (conspecific or heterospecific) of their nearest neighbor, we conducted permutation tests in which the observed mean nearest-neighbor distance for a given location in a given year was compared to a null distribution of mean distances derived by randomly allocating individuals among occupied nest boxes, i.e., maintaining the observed pattern of occupancy and species composition. $P$-values were calculated as the proportion of sampled permutations where the mean distance was greater than or equal to the observed mean distance, over 999 permutations. All analyses were considered significant at a probability value of $<0.05$. 
Fig. 1. Plans based on UK Ordnance Survey grid system of Riseholme Park (A) and Treswell Wood (B) showing the distribution of the woodland (indicated by solid black line) at each site. Circles indicate position of nest boxes in 2014 and the species occupying them.

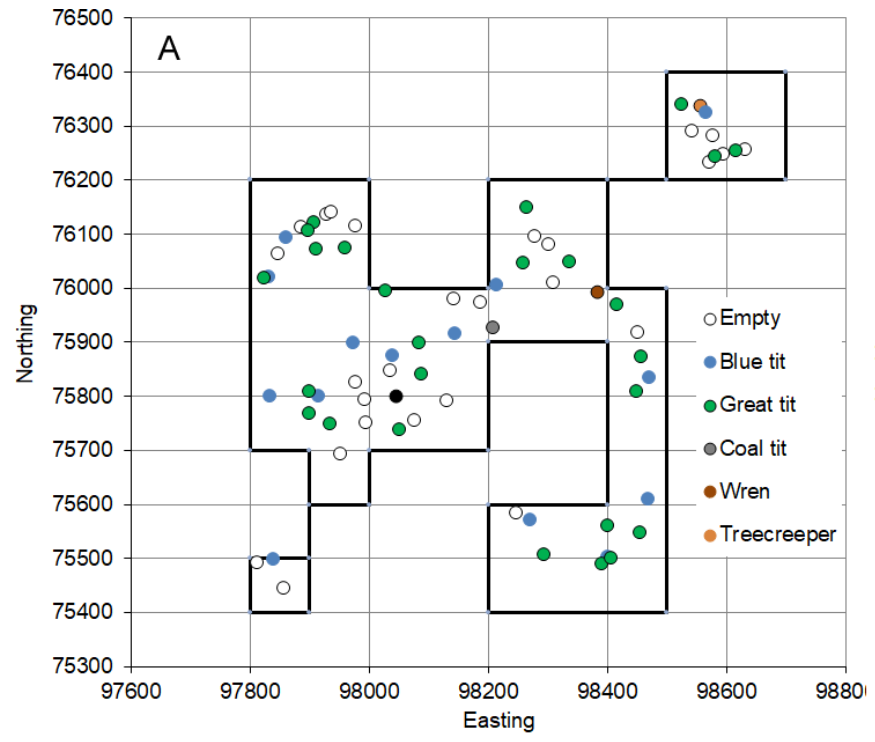

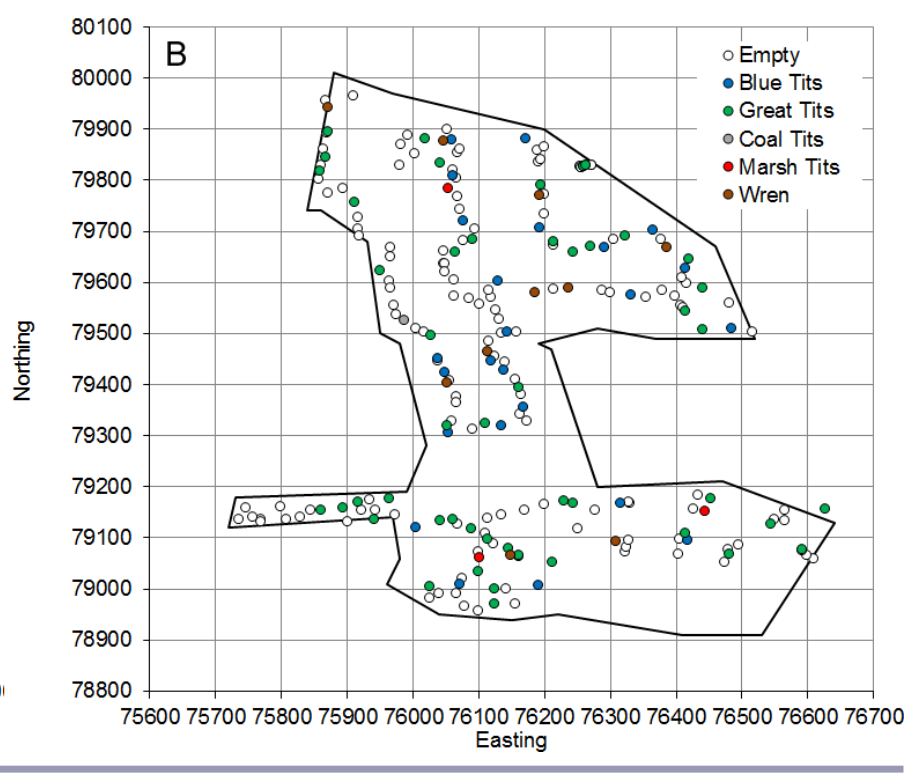

\section{RESULTS}

At Riseholme (e.g., Fig. 1A) all boxes were randomly dispersed (dispersion indices $\left(\chi^{2}\right)$ of $45-51, \mathrm{df}=38$ ) as were those occupied by both Great Tits (dispersion indices of $28-49$, $\mathrm{df}=38$ ) and Blue Tits (dispersion indices of $22-35, \mathrm{df}=38$ ). By contrast, at Treswell (e.g., Fig. 1B) the nest boxes exhibited a clumped distribution (dispersion indices of $102-143$, df = 58). Despite this the nest boxes occupied by both Great Tits and Blue Tits were randomly dispersed within the woodland (dispersion indices of $46-87$ and $42-68$, df $=38$, respectively). This observation was confirmed by the analysis of both nearest conspecific neighbor distances and nearest heterospecific neighbor distances, where both species exhibited random distribution patterns $(P>0.05)$ in all cases of comparison between conspecifics and heterospecifics. The only exceptions were overdispersed values between conspecific Blue Tits at Riseholme in 2010, 2013, and 2014.

At Riseholme the proportion of nest boxes occupied ranged from 0.468 to 0.647 of the available boxes, which was higher than at Treswell ( 0.374 to 0.554$)$. The number of occupied boxes did not correlate with the number of available boxes at Riseholme $\left(r_{\mathrm{s}}=\right.$ $0.410, \mathrm{DF}=3, P=0.493)$ but there was a positive correlation at Treswell $\left(r_{\mathrm{s}}=0.900, \mathrm{DF}=3, P=0.037\right)$. The minimum distances between nest boxes (irrespective of occupancy) at Riseholme were significantly $\left(t_{4}=9.59, P=0.001\right)$ longer than at Treswell (mean distances $=33.8 \pm 3.1 \mathrm{~m}$ at Riseholme and $20.1 \pm 0.7 \mathrm{~m}$ at Treswell). There was a significantly lower density of boxes at Treswell (mean $4.11 \pm$ SD 0.30 boxes per ha compared with 4.68 \pm 0.34 at Riseholme; $t_{7}=2.77, P=0.028$; Table 1 ).

In general there were more Great Tits nesting at both locations but at Riseholme Blue Tits formed a greater proportion of the combined population (average 2010-2014 of $0.42 \pm 0.09$ ) than at Treswell (average 2010-2014 of $0.32 \pm 0.04$ ). Density of boxes occupied by breeding Blue Tits at Riseholme was significantly higher than that observed at Treswell $(1.05 \pm 0.23$ versus 0.52 \pm 0.13 , respectively, $t_{6}=4.10, P=0.006$ ). Although the density of boxes occupied by Great Tits was higher at Riseholme compared with Treswell $(1.45 \pm 0.31$ versus $1.19 \pm 0.34$, respectively) this difference was not significant $\left(t_{7}=1.28, P=\right.$ 0.242).

There was a higher proportion of empty boxes nearest to the occupied box at Treswell compared with Riseholme $\left(F_{1,17}=5.32\right.$, $P=0.034)$ although the focal species occupying the box was not important $\left(F_{1,17}=0.69, P=0.419 ;\right.$ Fig. 2$)$. The proportion of instances when the nearest box contained a conspecific was generally lower than an empty box (Fig. 2) but the proportions were significantly higher for Great Tits than for Blue Tits $\left(F_{1,17}=\right.$ $11.19, P=0.004)$ irrespective of location $\left(F_{1,17}=0.00, P=0.982\right)$. For nearest boxes occupied by a heterospecific, irrespective of species (Fig. 2), both focal species (Blue Tits $>$ Great Tits; $F_{1,17}=$ 14.64, $P=0.001)$ and location were significant factors affecting the proportion of occupied boxes (Treswell $<$ Riseholme; $F_{1,17}=$ $8.42, P=0.010)$.

At both Riseholme and Treswell distances between conspecifics were greater for Blue Tits than Great Tits but for both species the distances were shorter at Treswell (Fig. 3). The distances between boxes containing conspecific birds were significantly affected by location and focal species but there was no significant interaction (Table 2). All pairwise comparisons were significant (Tukey test, $P<0.05$ ) except for between Blue Tits at Treswell and Great tits at Riseholme (Fig. 3). Distances between boxes occupied by heterospecifics were more similar to each other (Fig. 3). Location, focal species, and the interaction term were all significant factors in the model (Table 2). Pairwise comparisons indicated that the shorter distances between boxes for Blue Tits as the focal species in Treswell were significantly smaller than all other values (Fig. 3). 
Fig. 2. Mean $(+\mathrm{SD})$ proportions of the nest boxes that contained either no bird, a conspecific, or a heterospecific for Great Tits (Parus major) and Blue Tits (Cyanistes caeruleus) nesting at Riseholme Park or Treswell Wood.

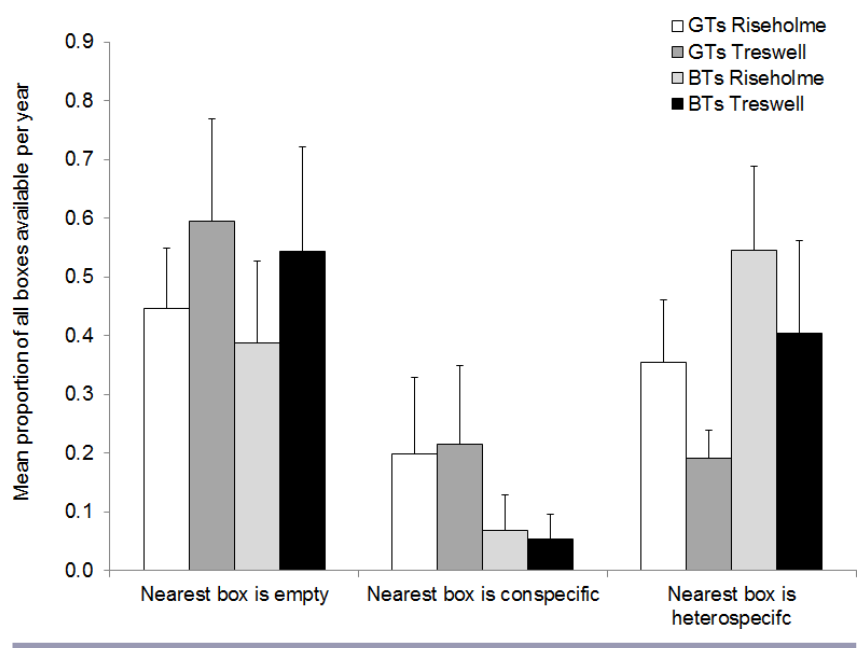

Fig. 3. Mean ( \pm SD) distances to a box nearest to a box containing a focal bird that contains either a conspecific or a heterospecific for Great Tits (Parus major) and Blue Tits (Cyanistes caeruleus) nesting at Riseholme Park or Treswell Wood. Columns with different superscripts, $\mathrm{x}, \mathrm{y}, \mathrm{z}$ (conspecific) or a,b (heterospecific), indicate significant differences at a $P$ value of 0.05 .

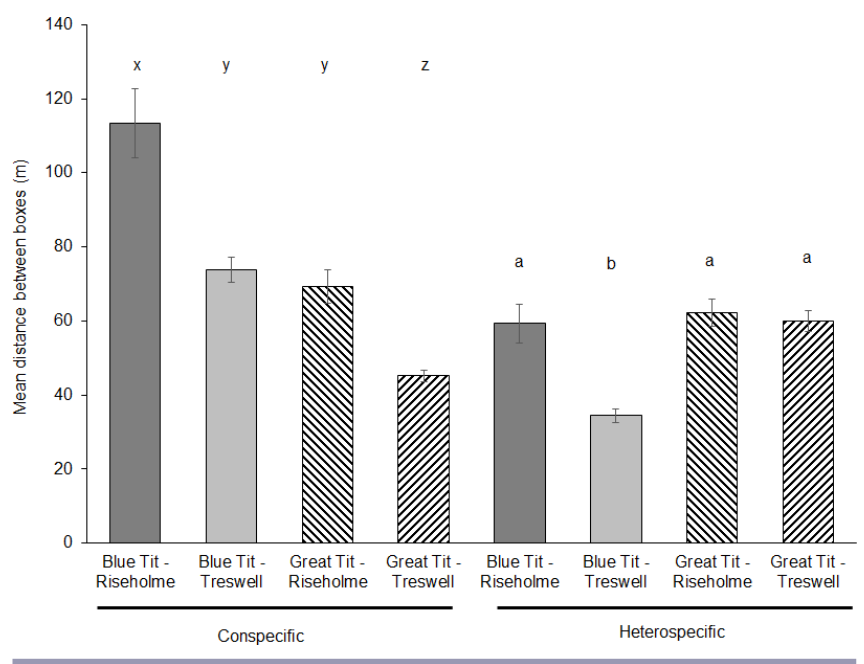

On average Blue Tits laid significantly more eggs than Great Tits irrespective of location (Fig. 4A; Table 3). By contrast, fledging success (as a proportion of clutch size) was higher for Great Tits although this was not significant (Fig. 4B; Table 3). For clutch size the distance between conspecifics was a significant covariate and focal species was significant (Table 3). In particular, for Blue Tits at Treswell larger clutch sizes were significantly correlated with distance between boxes containing conspecifics (Spearman's $\left.r_{\mathrm{s}}=0179, D F=133, P=0.046\right)$. By contrast, location and the interaction between location and focal species were not significant (Table 3). Heterospecific distance did not significantly covary with clutch size and was only significantly affected by focal species (Table 3). For the proportion of chicks fledged conspecific distance only approached significance although focal species was significant (Table 3). Heterospecific distance was not a significant covariate for proportion fledged and the only significant effect was location (Table 3).

Table 2. Results of GLMM analysis of variance to test the effects of focal species (Blue Tit, Cyanistes caeruleus, or Great Tit, Parus major), location (Riseholme Park or Treswell Wood), and the interaction on the distances between nest boxes occupied by conspecifics or heterospecifics. Distance values were $\log _{10}$ transformed prior to analysis.

\begin{tabular}{lccccc}
\hline \hline & \multicolumn{2}{c}{ Conspecific distance } & & \multicolumn{2}{c}{$\begin{array}{c}\text { Heterospecific } \\
\text { distance }\end{array}$} \\
\cline { 2 - 3 } \cline { 5 - 6 } & $\mathrm{F}_{1,545}$ & P-value & & $\mathrm{F}_{1,545}$ & P-value \\
& 75.10 & $<0.001$ & & 19.75 & $<0.001$ \\
\hline Focal species & 45.58 & $<0.001$ & & 24.94 & $<0.001$ \\
Location & 0.32 & 0.572 & & 7.22 & 0.007 \\
\hline Focal species*Location & & & & &
\end{tabular}

Table 3. Results of GLMM analysis of variance to test the effects of distance between occupied nest boxes containing conspecific or heterospecifics together with the fixed effects of focal species (Blue Tit, Cyanistes caeruleus, or Great Tit, Parus major), location (Riseholme Park or Treswell Wood), and the interaction on clutch size and proportion of the clutch that fledged. Distance values were $\log _{10}$-transformed prior to analysis.

\begin{tabular}{|c|c|c|c|c|}
\hline & \multicolumn{2}{|c|}{ Clutch size } & \multicolumn{2}{|c|}{ Proportion fledged } \\
\hline & $\mathrm{F}_{1,542}$ & $\mathrm{P}$-value & $\mathrm{F}_{1,542}$ & P-value \\
\hline Conspecific distance & 4.66 & 0.031 & 3.56 & 0.060 \\
\hline Focal species & 22.37 & $<0.001$ & 5.61 & 0.018 \\
\hline Location & 6.23 & 0.632 & 2.79 & 0.096 \\
\hline Focal species*Location & 3.16 & 0.076 & 1.82 & 0.178 \\
\hline Heterospecific distance & 1.33 & 0.249 & 0.04 & 0.839 \\
\hline Focal species & 34.34 & $<0.001$ & 3.45 & 0.640 \\
\hline Location & 0.03 & 0.871 & 4.94 & 0.027 \\
\hline Focal species*Location & 3.61 & 0.076 & 1.78 & 0.183 \\
\hline
\end{tabular}

\section{DISCUSSION}

Both geographical location and focal species significantly affected the distances between adjacent boxes containing conspecific individuals. For nest boxes containing heterospecific individuals distances were generally smaller but Blue Tits at Treswell occupied boxes much closer to a conspecific individual. Focal species was important in determining clutch size and the distance between adjacent boxes containing conspecifics was a significant covariate: in particular, at Treswell the greater the distance between two boxes containing Blue Tits then the larger the clutch 
size. This effect was not observed for clutch size in relation to heterospecific distance, nor was there any effect of distance on proportion of offspring fledged.

Fig. 4. Mean ( \pm SE) for $(A)$ mean clutch size and (B) the proportion of the clutch size that fledged for Blue Tits (Cyanistes caeruleus) and Great Tits (Parus major) from Riseholme Park and Treswell Wood.
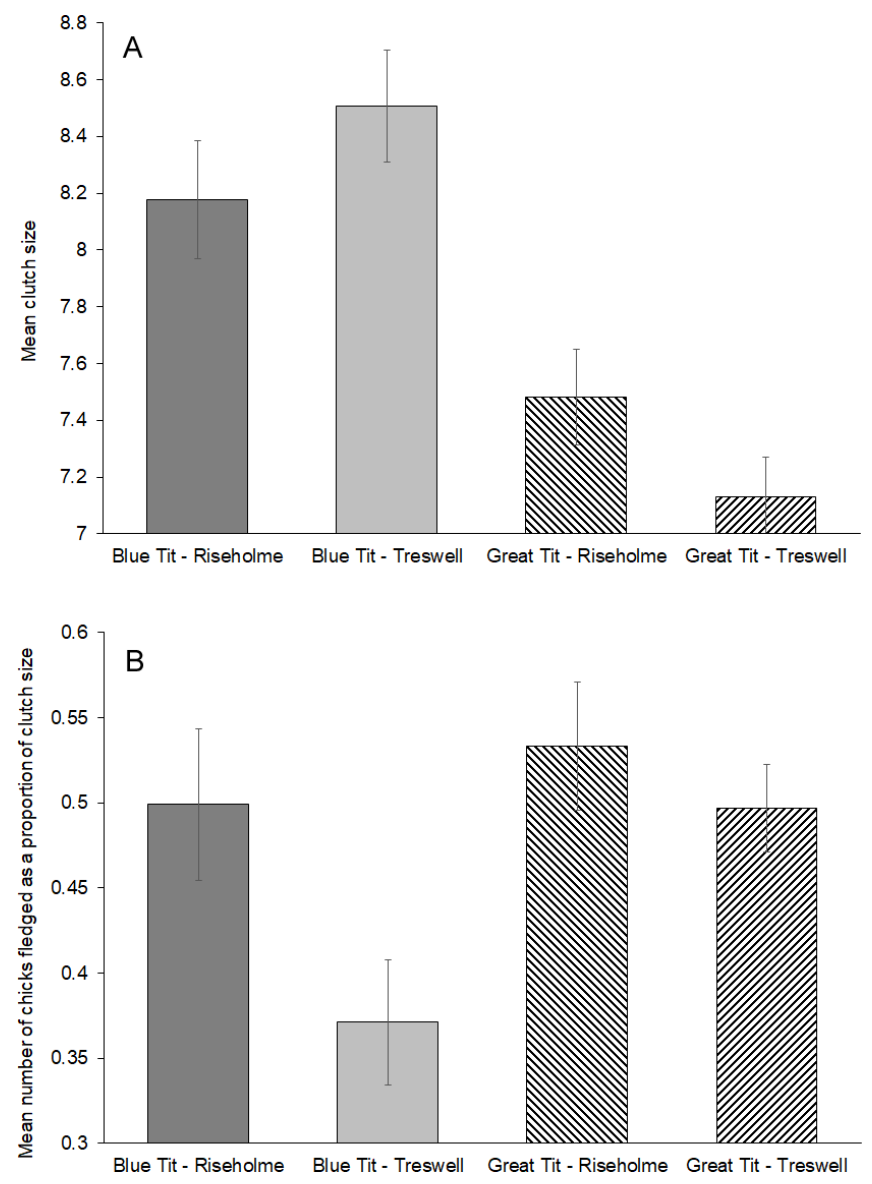

Nest boxes were supplied in excess at both Riseholme and Treswell Wood, which is typical of many study situations (e.g., Krebs 1971, Minot and Perrins 1986, Muldal et al. 1995, Mänd et al. 2005). Even though nest box distribution was clumped at Treswell, the two tit species were randomly dispersed within the woodland. Our results suggest that the distance between adjacent nest boxes was around half of the minimum distances actually used by birds (20$33 \mathrm{~m}$ compared with $60-70 \mathrm{~m}$, respectively) irrespective of species. Hence, the density of nest boxes could be strategically reduced to better reflect the observed mean distances between occupied boxes with probably little effect on nesting density. Coincidentally, at Riseholme, natural wastage (boxes rotted away or were stolen) meant that there was a 10\% drop in available nest boxes in 2016 yet nest box usage remained at the same levels as seen during 2015 (DCD, unpublished observations). Hence, for Great Tits and Blue Tits increasing the interbox distance to around $60 \mathrm{~m}$ would have little effect on breeding activity in the woodlands. This would free up boxes that could be used on other heavily managed woodland sites.
Provision of nest boxes does not preclude birds choosing natural nest cavities that exist within the habitat. Indeed, it is the birds that choose their nest sites rather than being forced to adopt sites provided by humans. Given that availability and utilization of natural cavities may require systematic searches to identify all nest sites, it can often be assumed that human management of woodland to remove dead wood can mean that natural cavities in trees may be in short supply (Newton 1994, Cockle et al. 2011). Under such conditions breeding in what appears to be an appropriate habitat, i.e., there is a foraging habitat, may be precluded through a lack of nest sites.

Being unaware of the number of natural nesting cavities has not precluded studies of reproductive breeding of birds using nest boxes in woodland (Krebs 1971, Green 1979, Minot and Perrins 1986). Generally, it can be assumed that most sites provide nest boxes in excess, which when combined with possible natural cavities, means that nest site availability is not limiting. A study in Canada showed that provision of nest boxes in a mature woodland habitat that tripled the availability of potential nest sites and produced a ninefold increase in density of Mountain Chickadee (Poecile gambeli) nests (Aitken and Martin 2012). Control sites showed no change over the same period and once the boxes were removed from test sites then density returned to previous levels. Presumably in many locations there is competition for nest sites irrespective of species. Interspecific interference is considered low between Blue Tits and Great Tits (Green 1979), so how do sympatric bird species provided with an excess of nest sites, distribute themselves relative to conspecifics and heterospecifics?

Although there seems to be little interspecific competition in nest site selection between Blue Tits and Great Tits in our study there is evidence that the dispersion of nesting attempts by heterospecifics may not be random in other species. Some heterospecifics may prefer to nest in close proximity because migrant species are informed of habitat quality by the presence of breeding resident species (Mönkkönen and Forsman 2002, Thomson et al. 2003). For instance, Pied Flycatchers (Ficedula hypoleuca) gained fitness benefits from nesting in close proximity to Great Tits (Loukola et al. 2014). In other instances, interaction may be more neutral. Muldal et al. (1985) showed experimentally that Tree Swallows (Tachycineta bicolor) occupy nest boxes that lie in close proximity to each other, in order to maximize the distance to a nest box containing a conspecific but did not show any spacing preference in relation to Mountain Bluebirds (Sialia currucoides) nesting in adjacent boxes. In other instances, nesting adjacent to a heterospecific can be disadvantageous. Breeding performance of Tree Swallows was reduced because of House Wrens (Troglodytes aedon) nesting nearby (Finch 1990). Collared Flycatchers (Ficedula albicollis) had reduced fledging success in areas where Blue Tits and Great Tits were at high densities (Gustafsson 1987).

The results of this study only reflect the use of boxes by birds rather than being a complete breeding record of the woodland, including nests in natural cavities. The study aimed to quantify use of the boxes provided and was not a complete breeding record of the sites. It was assumed that natural cavities were in relatively short supply. For instance, at Riseholme, there is intense management of the woodland to remove dead wood and we 
assumed that there were few natural nest cavities. The Riseholme site has been monitored from 2007 to 2017 and there has been a progressive increase in the number of Blue Tits breeding starting from an initial population of 5 breeding pairs to 23 in 2017. Great Tit numbers have been stable over the same period ( 20-22 breeding pairs). This suggests that the provision of nest boxes has allowed one species at least to colonize a previously unsuitable site. At Treswell, the woodland is heavily coppiced (MacColl et al. 2014), which removes mature trees and standing dead wood that can be sites of natural cavities. There were between $40-50$ Great Tit territories recorded in the wood during 2010-2014, which is about the same number (or fewer) of observed nests in boxes. For Blue Tits the 40-50 territories exceeded the number of nests in boxes suggesting that Blue Tits may be using natural cavities more than Great Tits but this requires further investigation. Provision of nest sites has also increased breeding opportunities for Great Tits nesting in Estonia (Mänd et al. 2009). Interestingly, removal of nest boxes reduced the number of breeding Great Tits in a woodland because of increased competition for natural cavities whereas Blue Tits did not change in breeding numbers because they were better able to exploit smaller natural cavities (East and Perrins 1988). An experimental study in Canada where access to nest cavities was blocked reduced breeding by European Starlings (Sturnus vulgaris) during and after the experimental period but numbers of Mountain Bluebirds increased breeding over the same period (Aitken and Martin 2008). It was suggested that the dominant Starlings suppressed breeding by Bluebirds but the lack of suitable nest sites for Starlings limited their population and so provided the Bluebirds the opportunity to increase their breeding opportunities.

Blue Tits at Treswell appeared to disperse more widely between nest boxes containing a conspecific than did the Great Tits at both locations, and were able to produce larger clutches as the distance increased. Blue Tits also seemed to nest nearer to heterospecifics whereas for Great Tits the species in the nearest occupied nest box did not appear to be of much relevance. The distances recorded between boxes containing Blue Tits were larger than between Great Tits and much greater than the $41-55 \mathrm{~m}$ reported for Pied Flycatchers (Harvey et al. 1984). Nesting closer to heterospecifics has been reported in colony-nesting Tufted Duck (Aythya fuligula) nesting in a Black-headed Gull (Larus ridibundus) colony in Scotland (Liordos and Lauder 2015) and for Black Skimmers (Rhynchos niger) nesting with Gull-billed Terns (Sterna nilotica) in Louisiana (Pius and Leberg 1997). It is unclear what factors impact on the distances between boxes between conspecifics and this is worthy of further research.

Fitness consequences of the spatial distribution of these two species were associated with changes in clutch size rather than relative fledging success and impacted on Blue Tits more than Great Tits, which generally produce smaller clutch sizes (Deeming and du Feu 2011). Collared Flycatchers suffered lower sizes and reduced fledging success when breeding tits were more abundant but distances between nest boxes were not reported (Gustafsson 1987). This may reflect the nutritional requirements to produce a large clutch: conspecifics nesting in close proximity may compete more intensely for food in the period leading up to clutch initiation.

For those open-nesting species, habitat heterogeneity and microhabitat requirements may also lead to nonrandom distribution of nests. Gates and Gysel (1978) showed that passerine nest distribution was not random and most species had preference for either a field-type or forest-type nesting environment. The presence of heterospecifics can also influence nest location (Mönkkönen and Forsman 2002, Thomson et al. 2003). It is possible that the nesting requirements of species interact with habitat heterogeneity and availability and so force birds to nest closer to one another than they would prefer. Perhaps this acts as a driver for intraspecific competition for the best nest sites with losing birds being forced to occupy marginal habitats.

By providing an excess of nest boxes, we may effectively reduce intra-specific competition among secondary cavity-nesting species because they have a wider range of possible nests sites (Mänd et al. 2005). However, providing nest boxes in marginal habitats may be creating an ecological trap for the subset of the population forced to breed in a marginal habitat for foraging or has increased predation risk (Mänd et al. 2005, Klein et al. 2007, Rodríguez et al. 2011). Moreover, the long-term value of nest boxes as breeding cavities has recently been questioned because boxes have lower humidity and poorer insulation than natural cavities in trees (Maziarz et al. 2017). We agree with Maziarz et al. (2017) that nest boxes should be regarded as a targeted and temporary intervention and in long-term retention of cavitybearing trees is a more sustainable, cost-effective measure. However, it is not always possible to manage sites in a way that natural cavities can replace artificial ones. In addition, it is important to point out that Maziarz et al. (2017) based their conclusion on their findings on chick mortality and incidence of invertebrate parasites yet ignored the effects of high humidity on the incubation parameters of the birds concerned despite the clear importance of nest humidity on controlling weight loss from eggs and hence their hatching success (Deeming 2011).

Modern conservation faces constant financial pressures and improving the efficiency of nest box dispersal in habitats where natural nest sites are rare would help make the use of boxes more cost effective. The data presented here suggest that nest boxes were located too close together and our results (see Fig. 3) imply that for tit species a minimum distance between boxes should be around $60 \mathrm{~m}$. We recommend that for other species providing nest boxes in excess may not always yield the most cost-effective conservation benefits. Better spatial distribution of the boxes that reflects actual dispersal distances of the bird species would allow a better distribution of resources.

Responses to this article can be read online at: http://www.ace-eco.org/issues/responses.php/1026

\section{Acknowledgments:}

Many thanks go to the many volunteers, particularly Richard du Feu, Phil May, John Clark, John Bartley, John Black, Dan Bardsley, Gill Bardsley, and Keith Stedman who monitor the nest boxes in Treswell Wood, and to Nottinghamshire Wildlife Trust for permission to use Treswell Wood. Many thanks to Tom Pike for invaluable advice on statistical analysis and for comments on the manuscript. Thanks also to Ian Hartley and two anonymous reviewers for comments that helped to improve previous drafts of this manuscript. 


\section{LITERATURE CITED}

Aitken, K. E. H., and K. Martin. 2008. Resource plasticity and community responses to experimental reduction of a critical resource. Ecology 89:971-980. http://dx.doi.org/10.1890/07-0711.1

Aitken, K. E. H., and K. Martin. 2012. Experimental test of nestsite limitation in mature mixed forests of central British Columbia, Canada. Journal of Wildlife Management 76:557-565. http://dx.doi.org/10.1002/jwmg.286

Britt, J., and D. C. Deeming. 2011. First egg date and air temperature affect nest construction in Blue Tits Cyanistes caeruleus but not in Great Tits Parus major. Bird Study 58:78-89. http://dx.doi.org/10.1080/00063657.2010.524916

Camprodon, J., J. Salvanyà, and J. Soler-Zurita. 2008. The abundance and suitability of tree cavities and their impact on hole-nesting bird populations in beech forests of NE Iberian Peninsula. Acta Ornithologica 43:17-31. http://dx.doi. org/10.3161/000164508X345293

Cockle, K. L., K. Martin, and T. Wesołowski. 2011. Woodpeckers, decay, and the future of cavity-nesting vertebrate communities worldwide. Frontiers in Ecology and the Environment 9:377-382. http://dx.doi.org/10.1890/110013

Colquhoun, M. K., and A. Morley. 1943. Vertical zonation in woodland bird communities. Journal of Animal Ecology 12:75-81. http://dx.doi.org/10.2307/1368

Deeming, D. C. 2011. Importance of nest type on the regulation of nest humidity in birds. Avian Biology Research 4:23-31. http:// dx.doi.org/10.3184/175815511X13013963263739

Deeming, D. C. 2013. Bird nests inside and out. Biologist 60:28-32.

Deeming, D. C., and C. R. du Feu. 2011. Long-term patterns in egg mortality during incubation and chick mortality during rearing in three species of tits in an English woodland. Bird Study 58:278-290. http://dx.doi.org/10.1080/00063657.2011.589429

du Feu, C. R. 2003. The BTO nest box guide. British Trust for Ornithology, Thetford, UK.

East, M. L., and C. M. Perrins. 1988. The effect of nest boxes on breeding populations of birds in broadleaved temperature woodlands. Ibis 130:393-401. http://dx.doi.org/10.1111/j.1474-919X.1988. tb00997.x

Finch, D. M. 1990. Effects of predation and competitor interference on nesting success of house wrens and tree swallows. Condor 92:674-687. http://dx.doi.org/10.2307/1368686

Fowler, J., L. Cohen, and P. Jarvis. 1997. Practical statistics for field biology. Second edition. Wiley, Chichester, UK.

Gates, J. E., and L. W. Gysel. 1978. Avian nest dispersion and fledging success in field-forest ecotones. Ecology 59:871-883. http://dx.doi.org/10.2307/1938540

Gosler, A. 1993. The Great Tit. Hamlyn, London, UK.

Green, R. F. 1979. A graph theoretical test to detect interference in selecting nest sites. Pages 439-452 in G. P. Patil and M. Rosenzweig, editors. Contemporary quantitative ecology and related economics. International Co-operative Publishing House, Fairland, Maryland, USA.
Gustafsson, L. 1987. Interspecific competition lowers fitness in collared flycatchers Ficedula albicollis: an experimental demonstration. Ecology 68:291-296. http://dx.doi.org/10.2307/1939260

Harvey, P. H., P. J. Greenwood, B. Campbell, and M. J. Stenning. 1984. Breeding dispersal of the pied flycatcher (Ficedula hypoleuca). Journal of Animal Ecology 53:727-736. http://dx.doi. org/10.2307/4655

Klein, Á., T. Nagy, T. Csörgõ, and R. Mátics. 2007. Exterior nestboxes may negatively affect Barn Owl Tyto alba survival: an ecological trap. Bird Conservation International 17:273-281. http://dx.doi.org/10.1017/S0959270907000792

Krebs, J. R. 1971. Territory and breeding density in the great tit, Parus major L. Ecology 52:2-22. http://dx.doi.org/10.2307/1934734

Lima, C. C., and C. M. Garcia. 2016. Pre- and post-experimental manipulation assessments confirm the increase in number of birds due to the addition of nest boxes. PeerJ 4:e1806. http://dx.doi. org/10.7717/peerj.1806

Liordos, V., and A. W. Lauder. 2015. Factors affecting nest success of Tufted Ducks (Aythya fuligula) nesting in association with Black-headed Gulls (Larus ridibundus) at Loch Leven, Scotland Waterbirds 38:208-213. http://dx.doi.org/10.1675/063.038.0211

Loukola, O. J., T. Laaksonen, J.-T. Seppänen, and J. T. Forsman. 2014. Active hiding of social information from informationparasites. BMC Evolutionary Biology 14:32. http://dx.doi. org/10.1186/1471-2148-14-32

MacColl, A. D. C., C. R. du Feu, and S. P. Wain. 2014. Significant effects of season and bird age on use of coppice woodland by songbirds. Ibis 156:561-575. http://dx.doi.org/10.1111/ibi.12152

Mänd, R., A. Leivits, M. Leivits, and N. L. Rodenhouse. 2009. Provision of nest boxes raises the breeding density of Great Tits Parus major equally in coniferous and deciduous woodland. Ibis 151:487-494. http://dx.doi.org/10.1111/j.1474-919X.2009.00929. $\mathrm{x}$

Mänd, R., V. Tilgar, A. Lõhmus, and A. Leivits. 2005. Providing nest boxes for hole-nesting birds - Does habitat matter? Biodiversity \& Conservation 14:1823-1840. http://dx.doi. org/10.1007/s10531-004-1039-7

Mazgajski, T. D. 2009. Breeding success of hole-nesting birds effects of nest sites characteristics and predators avoidance strategies. Wiadomosci Ekologiczne 55:159-183.

Maziarz, M., R. K. Broughton, and T. Wesołowski. 2017. Microclimate in tree cavities and nest-boxes: implications for holenesting birds. Forest Ecology and Management 389:306-313. http://dx.doi.org/10.1016/j.foreco.2017.01.001

Milligan, M. C., and J. L. Dickinson. 2016. Habitat quality and nest-box occupancy by five species of oak woodland birds. Auk 133:429-438. http://dx.doi.org/10.1642/AUK-15-187.1

Minot, E. O., and C. M. Perrins. 1986. Interspecific interference competition - nest sites for blue and great tits. Journal of Animal Ecology 55:331-350. http://dx.doi.org/10.2307/4712

Mönkkönen, M., and J. T. Forsman 2002. Heterospecific attraction among forest birds: a review. Ornithological Science 1:41-51. http://dx.doi.org/10.2326/osj.1.41 
Muldal, A., H. L. Gibbs, and R. J. Robertson. 1985. Preferred nest spacing of an obligate cavity-nesting bird, the tree swallow. Condor 87:356-363. http://dx.doi.org/10.2307/1367216

Newton, I. 1994. The role of nest sites in limiting the numbers of hole-nesting birds: a review. Biological Conservation 70:265-276. http://dx.doi.org/10.1016/0006-3207(94)90172-4

Pius, S. M., and P. L. Leberg. 1997. Aggression and nest spacing in single and mixed species groups of seabirds. Oecologia 111:144-150. http://dx.doi.org/10.1007/s004420050218

Remm, J., A. Lõhmus, and K. Remm. 2006. Tree cavities in reverine forests: what determines their occurrence and use by holenesting passerines? Forest Ecology and Management 221:267-277. http://dx.doi.org/10.1016/j.foreco.2005.10.015

Rodríguez, J., J. M. Avilés, and D. Parejo. 2011. The value of nest boxes in the conservation of Eurasian Rollers Coracias garrulus in southern Spain. Ibis 153:735-745. http://dx.doi.org/10.1111/ j.1474-919X.2011.01161.X

Sánchez, S., J. J. Cuervo, and E. Moreno. 2007. Suitable cavities as a scarce resource for both cavity and non-cavity nesting birds in managed temperate forests. A case study in the Iberian Peninsula. Ardeola 54:261-274.

Surgey, J., C. R. du Feu, and D. C. Deeming. 2012. Opportunistic use of a wool-like artificial material as lining of Tit (Paridae) nests. Condor 114:385-392. http://dx.doi.org/10.1525/cond.2012.110111

Thomson, R. L., J. T. Forsman, and M. Mönkkönen. 2003. Positive interactions between migrant and resident birds: testing the heterospecific attraction hypothesis. Oecologia 134:431-438. http://dx.doi.org/10.1007/s00442-002-1140-0 